\title{
The Possible Involvement of Exogenous Gibberellic Acid on Nitrogen Assimilating Enzyme Activity and Total Nitrogen Content in Chickpea (Cicer aeritinum L.) Genotypes
}

\author{
Preeti Singh Arya ${ }^{1 *}$, Jagdish Singh Arya ${ }^{2}$ and R.P. Singh ${ }^{1}$ \\ ${ }^{1}$ Department of Biochemistry, Narendra Deva University of Agriculture \& Technology, \\ Kumarganj, Faizabad, U.P. 224 229, India \\ ${ }^{2}$ Defence Institute of High Altitude Research, DRDO C/o 56 APO, India \\ *Corresponding author
}

\section{A B S T R A C T}

Five kabuli chickpea genotypes and desi chickpea genotypes were grown during rabi season of 2010-11 at Student's Instructional Farm of N.D. University of Agriculture \&

Keywords

Chickpea (Cicer aeritinum L.), Genotypes

\section{Article Info}

Accepted: 20 March 2018 Available Online: 10 April 2018
Technology, Faizabad. 0 ppm (control condition), 15 ppm and $30 \mathrm{ppm}$ concentrations of $\mathrm{GA}_{3}$ were applied as foliar application at flower initiation stage (65-70 days after sowing) to the plants. Nitrate reductase enzyme and nitrite reductase enzyme activity were evaluated in leaves of chickpea genotypes at flower initiation stage, 50\% flowering stage and at the time of maturity whereas total nitrogen content was estimated in pods of chickpea genotypes at 20,40 and 60 days after flowering. Both the enzyme's activity was found highest at the flower initiation stage and lowest at the time of maturity. Total nitrogen content in chickpea pods was found highest at 20 days after flowering and lowest at 60 days after flowering. At the time of $50 \%$ flowering and maturity nitrate and nitrite reductase enzyme activity was found maximum in control condition whereas with the foliar application of $30 \mathrm{ppm}$ of gibberellic acid, these enzymes gave better response at flower initiation stage. Total nitrogen content was found maximum with the $30 \mathrm{ppm}$ gibberellic acid. Desi genotype IPC 2004-90 gave better response among all the genotypes regarding the enzyme activity and total nitrogen content.

\section{Introduction}

Chickpea (Cicer arietinum L.) commonly known as Bengal Gram is the most important grain legume crop in the world and major pulse crop in India (Rao et al., 1999; Seabra et al., 2001). It is an important rabi crop originated in Western Asia (Bouhadida et al., 2015), from where it spread in India and rest of the world, mostly grown in tropical, subtropical and temperate regions. India is a leading chickpea growing country accounting for about 65 per cent of the world production (Alka Dev, 2017). In India, the area under chickpea was 8.74 million hectare with a production of 7.35 million tonnes with productivity of $841 \mathrm{~kg} / \mathrm{ha}$ during Rabi 2009-10 (Singh, 2010). Chickpea is the third most important food legume grown in the world after beans and peas. Chickpea is an important 
pulse crop due to its intrinsic value in terms of higher protein content, nitrogen fixing ability, diversified uses and indispensability as alternative crop for crop diversification. Chickpea seeds are good source nutritionally rich of protein (Vesna, 2015), phosphorous, calcium important vitamins such as riboflavin, niacin, thiamin, folate, the vitamin A precursor $\beta$-caroteneand fiber content and relatively low in antinutritional factors such as trypsin inhibitor.(Rathore and Sharma, 2003). Chickpea are nutritionally rich in the essential amino acids except sulphur-containing amino acids (Jukanti et al., 2012).

Gibberellic acid is a very potent hormone whose natural occurrence in plants control their development. Since GA regulates growth, applications of very low concentrations can have a profound effect while too much will have the opposite effect. Gibberillic acid $\left(\mathrm{GA}_{3}\right)$ affects activity of different enzymes especially amylase and increases mobilization of starch granules in cotyledons thus, stimulating germination and growth (Kaur et al., 1998). Nitrate reductase mediates the reduction of nitrate to nitrite, which is regarded as a rate limiting step in plant growth and development (Solmonson and Barber, 1990) and nitrite reductase mediates the reduction of nitrite to ammonia. Soil salinity is one of the major environmental stresses for cultivation of crops. The inhibitory effect of salinity on nitrate reductase activity is known in many crops (Katiyar and Dubey, 1992; Khan, 1996; Garg et al., 1997). The role of an agriculturist is, therefore, to manipulate the crop in order to counteract the influence of salt stress, and boost performance even under saline conditions. Attention has now come to be focused on the use of plant growth regulators, such as gibberellic acid $\left(\mathrm{GA}_{3}\right)$, which are known to be importantly concerned in the regulation of plant responses to the external environment and to control a number of stress-induced genes (Naqvi, 1994). The aim of the present study was to determine how $\mathrm{GA}_{3}$ affects nitrate and nitriereducatase activity in leaf and total nitrogen content in pods of chickpea genotypes at different stages of development.

\section{Materials and Methods}

The present investigation was conducted at Student's Instructional Farm of N.D. University of Agriculture and Technology, Kumarganj, Faizabad during rabi season of 2010-11. Five kabuli genotypes namely BG1053, GLK-24092, CSJK-27, IPCK 2006-37 and GNG-1888 and desi genotypes namely NDG-30, JSC-48, IPC 2004-90, GCP-105 and NDG 5-21 were grown at the experimental site and the experiment was laid out in Randomized Block Design. 0 ppm (control condition), $15 \mathrm{ppm}$ and $30 \mathrm{ppm}$ concentrations of $\mathrm{GA}_{3}$ were applied as foliar application at flower initiation stage (65-70 days after sowing) to the plants. The nitrate reductase and nitrite reductase activity was measured in chickpea leaves at flower initiation stage (6570 days after sowing), 50 percent flowering (75-85 days after sowing) and at the time of maturity (125-140 days after sowing).

The activity of nitrate reductase enzyme was measured by the spectrophotometric determination, by the method described by Nicholos and Nasen in 1957. Nitrite reductase activity was estimated by Ferari and Varner (1971) method. Total Nitrogen content in chickpea pods was determined by the Kjeldahl method (A.O.A.C., 1970) at 20, 40 and 60 days after flowering.

\section{Results and Discussion}

The nitrate reductase enzyme activity in chickpea leaves (Table 1) was recorded in the range of 63.55 to $66.83 \mu \mathrm{mol} \mathrm{hr} \mathrm{gr}^{-1}, 54.18$ to $58.67 \mu \mathrm{mol} \mathrm{hr}^{-1} \mathrm{~g}^{-1}$ and 49.44 to $53.97 \mu \mathrm{mol}$ $\mathrm{hr}^{-1} \mathrm{~g}^{-1}$ during flower initiation stage, $50 \%$ 
flowering and at the time of maturity of chickpea leaves in the year. Maximum activity of nitrate reductase in chickpea leaves was obtained in IPC 2004-90 during flower initiation stage $\left(66.83 \mu \mathrm{mol} \mathrm{hr} \mathrm{hr}^{-1}\right)$, during $50 \%$ flowering stage $\left(58.67 \mu \mathrm{mol} \mathrm{hr} \mathrm{g}^{-1}\right)$ and at the time of maturity $\left(53.97 \mu \mathrm{mol} \mathrm{hr} \mathrm{g}^{-1}\right)$. The minimum activity of nitrate reductase was observed in GLK-24092 (63.55 $\mu$ mol hr${ }^{-1} \mathrm{~g}^{-1}$, $54.18 \mu \mathrm{mol} \mathrm{hr} \mathrm{g}^{-1}, 49.44 \mu \mathrm{mol} \mathrm{hr} \mathrm{g}^{-1}$ ) at flower initiation stage. $50 \%$ flowering stage and at the time of maturity respectively. All the chickpea varieties regarding nitrate reductase activity in chickpea leaves was found significant in the present investigation. The nitrate reductase activity in chickpea leaves decreased continuously as the number of days after sowing increased. The nitrate reductase activity was found significant regarding the application of $\mathrm{GA}_{3}$ concentrations. It ranged between 63.74to $66.13 \mu \mathrm{mol} \mathrm{hr}{ }^{-1} \mathrm{~g}^{-1}, 56.05$ to $57.55 \mu \mathrm{mol} \mathrm{hr}^{-1}$ $\mathrm{g}^{-1}$ and 50.95to $52.32 \mu \mathrm{mol} \mathrm{hr} \mathrm{g}^{-1}$ during flower initiation stage, $50 \%$ flowering and at the time of maturity. Maximum nitrate reductase activity was obtained in $30 \mathrm{ppm} \mathrm{GA}_{3}$ concentration $\left(66.13 \mu\right.$ mol $\left.\mathrm{hr}^{-1} \mathrm{~g}^{-1}\right)$ and minimum in control treatment $\left(63.74 \mu \mathrm{mol} \mathrm{hr}{ }^{-}\right.$ $\left.{ }^{1} \mathrm{~g}^{-1}\right)$ at flower initiation stage. Whereas for $50 \%$ flowering and at the time of maturity, maximum nitrate reductase activity were recorded in control $\left(57.55 \mu \mathrm{mol} \mathrm{hr} \mathrm{g}^{-1}\right.$ and $52.32 \mu \mathrm{mol} \mathrm{hr} \mathrm{g}^{-1}$ ) and minimum in $15 \mathrm{ppm}$ $\mathrm{GA}_{3}$ concentration $\left(56.05 \mu \mathrm{mol} \mathrm{hr} \mathrm{g}^{-1}, 50.95 \mu\right.$ $\left.\mathrm{mol} \mathrm{hr} \mathrm{g}^{-1}\right)$. The nitrate reductase activity was found significant regarding the application of $\mathrm{GA}_{3}$ concentrations. Nitrate reductase enzyme is substrate inducible enzyme, its' induction is closely dependent on the availability of nitrate and the enzyme is found in cytosol of plant cells in leaves. The results are in close agreement with Garg and Singla (2005) who reported that nitrate reductase activity in the leaves in the chickpea cultivars decreased however maximum activity of this enzyme was observed after 70 days after sowing.
Similar trend were also observed in the present investigation. This decline in nitrate reductase activity may be due to enhanced degradation of nitrogen reductase, the inhibition of nitrate reductase activity may be due to reduced rate of enzyme synthesis due to salt ions and salinity. Nitrate reductase activity constitutes the main source of inorganic nitrogen for crop plants. The activity of this enzyme is reduced during senescence due to break down of proteins. The foliar application of bioregulators increased the Nitrate reductase activity. This might be due to enhancement of nitrogen uptake and photosynthetic activity due to higher chlorophyll content. All the bioregulators treatments as foliar spray increased the chlorophyll content considerably (Senthil et al., 2008). It is generally believed that nitrate reductase activity depends on the activity of substrate and proteinaceous compounds and therefore it is suggested that the application of plant growth regulators results in the enhanced nitrate uptake by plants (Merentoshi et al., 2011). According to Jeyakumar et al., (2008) the stimulated nitrate reductase might be due to the enhancement of nitrogen or nitrate uptake by plants and the possible role of gibberellic acid in activation of inactive nitrate reductase proteins and prevention of enzyme degradation by proteolysis. Vyas and Puranik (1993) observed that sucrose enhances the stability of nitrate reductase enzyme and mobilize endogenous nitrate pool for enzyme activity. Sugar may provide carbon skeleton for amino acid biosynthesis, hence they should increase the activities of the enzyme involved in primary amination.

The nitrite reductase enzyme activity in chickpea leaves (Table 2) was obtained in the range of 147.42 to $150.35 \mu \mathrm{mol} \mathrm{hr}^{-1} \mathrm{~g}^{-1}$, 128.92to $138.31 \mu \mathrm{mol} \mathrm{hr} \mathrm{gr}^{-1}$ and 119.69to $122.92 \mu \mathrm{mol} \mathrm{hr}^{-1} \mathrm{~g}^{-1}$. The varieties regarding nitrite reductase activity in chickpea leaves during flower initiation stage was found non- 
significant but it was statistically significant regarding 50\% flowering and at the time of maturity. The maximum activity of nitrite reductase was recorded in IPC 2004-90 $\left(138.31 \mu \mathrm{mol} \mathrm{hr} \mathrm{g}^{-1}, 122.92 \mu \mathrm{mol} \mathrm{hr} \mathrm{gg}^{-1}\right)$ followed by NDG 5-21 (137.11 $\mu \mathrm{mol} \mathrm{hr}{ }^{-1} \mathrm{~g}^{-1}$,

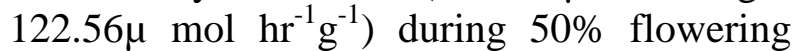
and at the time of maturity. The minimum activity of nitrite reductase was obtained in GLK $24092\left(128.92 \mu \mathrm{mol} \mathrm{hr} \mathrm{g}^{-1}\right.$ and $119.69 \mu$ mol hr $\mathrm{g}^{-1}$ ) during $50 \%$ flowering and at the time of maturity. The activity of nitrite reductase was decreased as the number of days after sowing increased in the present investigation. The nitrite reductase activity was found significant regarding the $\mathrm{GA}_{3}$ concentration nitrite reductase activity in chickpea leaves ranged between 145.18to $152.52 \mu \mathrm{mol} \mathrm{hr} \mathrm{gr}^{-1}$, 132.31to $134.88 \mu \mathrm{mol}$ $\mathrm{hr}^{-1} \mathrm{~g}^{-1}$ and 120.01 to $121.85 \mu \mathrm{mol} \mathrm{hr} \mathrm{g}^{-1}$ during flower initiation stage, $50 \%$ flowering and at the time of maturity respectively. Maximum nitrite reductase activity was obtained in $30 \mathrm{ppm}$ concentration $\left(152.52 \mu \mathrm{mol} \mathrm{hr} \mathrm{g}^{-1}\right)$ and minimum in control treatment $(145.18 \mu \mathrm{mol}$ $\left.\mathrm{hr}^{-1} \mathrm{~g}^{-1}\right)$ at the flower initiation stage. At $50 \%$ flowering and maturity maximum nitrite reductase activity was recorded in control treatment $\left(134.88 \mu \mathrm{mol} \mathrm{hr} \mathrm{g}^{-1}\right.$ and $121.85 \mu$ mol $\mathrm{hr}^{-1} \mathrm{~g}^{-1}$ ) and minimum in $15 \mathrm{ppm}$ concentration $\left(132.31 \mu \mathrm{mol} \mathrm{hr} \mathrm{g}^{-1}, 120.01 \mu\right.$ mol hr $\mathrm{g}^{-1}$ ).

The activity of nitrite reductase was decreased as the number of days after sowing increased in the present investigation. Nitrite reductase enzyme is a substrate inducible enzyme, its' induction is closely dependent on the availability of nitrate and the enzyme is found in chloroplasts in leaves. Maximum NiR activity in leaves appeared at flower initiation stage, thereafter activities of these enzymes declined. NR and NiR enzymes are sensitive to alkalinity and their activities decreased with increasing level of alkalinity in the soil. The results are in close agreement with Garg and
Singla (2005). Nitrogenase activity generally increased with plant age or decreased at flowering stage (Bidlack et al., 2001). Dey and Srivastava (2006) reported significant increase in nitrite reductase activity with the increase in concentrations of gibberellic acid. Since NR and NIR both are the substrate inducible enzymes, their induction are closely dependent on the availability of nitrate as reported by Datta and Sharma (1999) and Fatima et al., (2008) also observed that seed soaking treatments of growth regulators have profound effect in increasing soil nitrate while gibberellic acid and kinetin brought considerable variations in chickpea nodulation.

Total nitrogen content in chickpea pods (Table 3) ranged between 5.95to 6.10\%, 4.59to $4.99 \%, 3.44$ to $3.83 \%$ at 20,40 and 60 days after flowering. All the varieties of chickpea regarding total nitrogen content at 40 and 60 days after flowering varied significantly but at 20 days after flowering there were found nonsignificant variations. Maximum total nitrogen content was found in IPC 2004-90 $(4.99 \%$, $3.83 \%$ ) followed by NDG 5-21(4.94\%, $3.69 \%$ ) and minimum content was recorded in NDG 30 (4.59\%, 3.44\%). Total nitrogen content in chickpea pods decreased as the number of days after flowering increased. The total nitrogen content increased significantly by the application of $\mathrm{GA}_{3}$ concentrations at 20 and 40 days after flowering. The total nitrogen content varied between 5.94 to $6.19 \%, 4.71$ to $4.95 \%$ at 20 and 40 days after flowering. Maximum total nitrogen content was obtained in $30 \mathrm{ppm} \mathrm{GA}_{3}$ concentration $(6.19 \%, 4.95 \%)$ and minimum content in control treatment $(5.94 \%, 4.71 \%)$ at 20 and 40 days after flowering. Among the interaction effect, total nitrogen content was found significant at 40 days after flowering. However, the interaction between varieties and $\mathrm{GA}_{3}$ concentration was found non-significant at 20 and 60 days after flowering. 
Table.1 Influence of gibberellic acid on nitrate reductase enzyme activity $\left(\mu\right.$ molhr$\left.^{-1} \mathrm{~g}^{-1}\right)$ in chickpea leaves




Table.2 Influence of gibberellic acid on nitrite reductase enzyme activity $\left(\mu \mathrm{mol} \mathrm{hr}^{-1} \mathrm{~g}^{-1}\right)$ in chickpea leaves

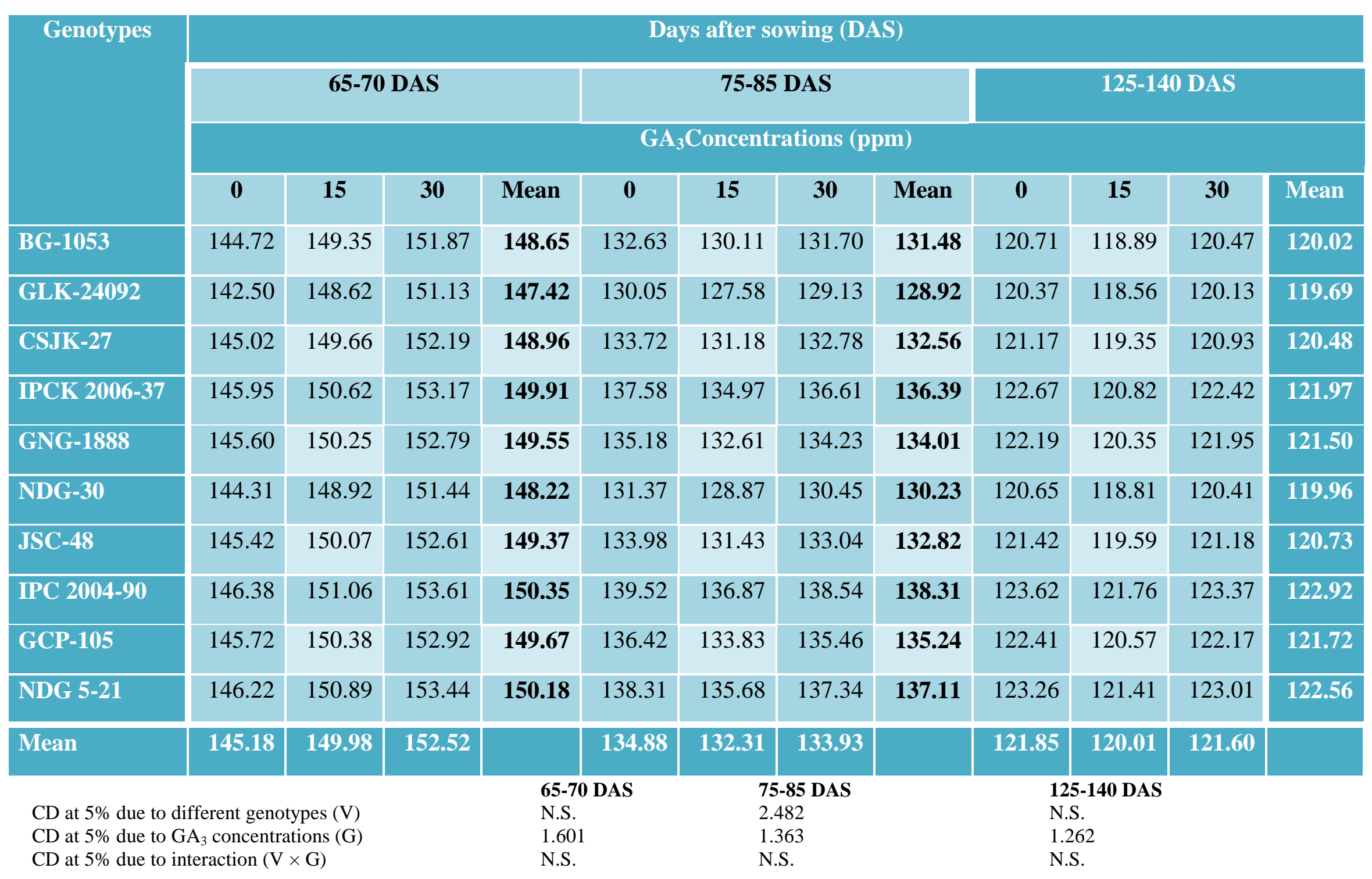


Table.3 Influence of gibberellic acid on total nitrogen content (\%) in chickpea pods

\begin{tabular}{|c|c|c|c|c|c|c|c|c|c|c|c|c|}
\hline & \multicolumn{12}{|c|}{ Days after flowering (DAF) } \\
\hline & \multicolumn{4}{|c|}{$20 \mathrm{DAF}$} & \multicolumn{4}{|c|}{$40 \mathrm{DAF}$} & \multicolumn{4}{|c|}{$60 \mathrm{DAF}$} \\
\hline & \multicolumn{12}{|c|}{$\mathrm{GA}_{3}$ Concentrations (ppm) } \\
\hline Genotypes & 0 & 15 & 30 & Mean & 0 & 15 & 30 & Mean & $\mathbf{0}$ & 15 & 30 & Mean \\
\hline BG-1053 & 5.97 & 6.02 & 6.22 & 6.07 & 4.73 & 4.77 & 4.97 & 4.82 & 3.60 & 3.63 & 3.64 & 3.62 \\
\hline GLK-24092 & 5.95 & 6.00 & 6.20 & 6.05 & 4.69 & 4.73 & 4.93 & 4.78 & 3.59 & 3.60 & 3.63 & 3.61 \\
\hline CSJK-27 & 5.93 & 5.98 & 6.18 & 6.03 & 4.66 & 4.70 & 4.90 & 4.75 & 3.55 & 3.58 & 3.59 & 3.57 \\
\hline IPCK 2006-37 & 5.98 & 6.03 & 6.23 & 6.08 & 4.78 & 4.82 & 5.02 & 4.87 & 3.63 & 3.66 & 3.67 & 3.65 \\
\hline GNG-1888 & 5.99 & 6.04 & 6.24 & 6.09 & 4.81 & 4.85 & 5.05 & 4.90 & 3.65 & 3.68 & 3.69 & 3.67 \\
\hline NDG-30 & 5.85 & 5.90 & 6.10 & 5.95 & 4.50 & 4.54 & 4.74 & 4.59 & 3.42 & 3.45 & 3.45 & 3.44 \\
\hline $\mathrm{JSC}-48$ & 5.87 & 5.92 & 6.12 & 5.97 & 4.57 & 4.61 & 4.81 & 4.66 & 3.50 & 3.53 & 3.53 & 3.52 \\
\hline IPC 2004-90 & 5.99 & 6.04 & 6.24 & 6.09 & 4.90 & 4.94 & 5.14 & 4.99 & 3.80 & 3.84 & 3.84 & 3.83 \\
\hline GCP-105 & 5.90 & 5.95 & 6.15 & 6.00 & 4.62 & 4.66 & 4.86 & 4.71 & 3.55 & 3.58 & 3.59 & 3.57 \\
\hline NDG 5-21 & 6.00 & 6.05 & 6.25 & 6.10 & 4.85 & 4.89 & 5.09 & 4.94 & 3.67 & 3.70 & 3.71 & 3.69 \\
\hline Mean & 5.94 & 5.99 & 6.19 & & 4.71 & 4.75 & 4.95 & & 3.60 & 3.63 & 3.63 & \\
\hline $\begin{array}{l}\mathrm{CD} \text { at } 5 \% \text { due to } \\
\mathrm{CD} \text { at } 5 \% \text { due to } \\
\mathrm{CD} \text { at } 5 \% \text { due to }\end{array}$ & $\begin{array}{l}\text { th genot } \\
\text { ncentra } \\
\text { ion }(\mathrm{V}>\end{array}$ & $\begin{array}{l}\text { s (V) } \\
\text { s (G) }\end{array}$ & & & $\begin{array}{l}\text { 20 DAF } \\
\text { N.S. } \\
0.067 \\
\text { N.S. }\end{array}$ & $\begin{array}{l}\mathbf{4 0} \\
0.0 \\
0.0 \\
\text { N. }\end{array}$ & & $\begin{array}{l}\text { 60 DAF } \\
0.069 \\
\text { N.S. } \\
\text { N.S. }\end{array}$ & & & & \\
\hline
\end{tabular}


Total nitrogen content was observed maximum in genotype JSC 48 at the $\mathrm{GA}_{3}$ concentration at $15 \mathrm{ppm}$ followed by genotype IPC 2004-90 at the $\mathrm{GA}_{3}$ concentration at $15 \mathrm{ppm}$ while minimum total nitrogen content was recorded in genotype GCP 105 where no gibberellic acid was applied. Tyagi et al., (1982) reported that after flowering there is a considerable mobilization of nitrogen contents from leaves to seeds. According to Patil and Ghuge (1988) nitrogen content was higher at 30 days after sowing and lowest at 60 days after sowing. The total content was found higher initially and then decreased. Total protein content estimated on the basis of nitrogen content was found $38 \%$ initially and $22 \%$ in mature seeds. Developing seeds did not show a linear increase in total protein content and this could be due to higher content of free amino acid pool during early stages of development (Mittal and Koundal, 1990). GA 3 increases membrane permeability and an increase in membrane permeability would facilitate absorption and utilization of mineral nutrients and transport of assimilates.(Khan et al., 2006) $\mathrm{GA}_{3}$ treatments may stimulate the development of xylem and phloem and in return increases flow and deposition of assimilation products to seeds (Secer, 1989 and Kaya et al., 2010). Gibberellic acid increased the availability of minerals as described by Raifa et al., 2005.

Khan et al., (2002) reported that foliar application of gibberellic acid could enhance nitrogen use efficiency and thus the crop growth. Similarly, the effect of $\mathrm{GA}^{3}$ spray on plant and seed Nitrogen content was found to be significant. Plants accumulated more $\mathrm{N}$ in the vegetative parts and seeds in GA3-treated plants that received an optimal $\mathrm{N}$ application. GA3-sprayed plants utilised soil applied $\mathrm{N}$ more effectively and increased its partitioning into seeds. The enhancement in nutrient utilisation by GA3 possibly occurred through its effect on nitrate reductase activity (Khan et al., 1996), to meet the demand of $\mathrm{N}$ by the enhanced top growth

From the results obtained it may be concluded that desi genotype IPC 2004-90 showed better performance over other genotypes. Nitrate reductase activity, nitrite reductase activity and total nitrogen content decreased with the increase in days after sowing and flowering. Foliar application of 30ppm gibberellic acid was upper hand for the nitrogen assimilating enzyme activity at flower initiation stage but control condition was better for $50 \%$ flowering and at the time of maturity. Total nitrogen content showed superior response to $30 \mathrm{ppm}$ gibberellic acid concentration at all the stages of development.

\section{References}

A.O.A.C. 1970. Association of Official Agriculture Chemists, Official Method of analysis. $11^{\text {th }}$ ed. Washington, D.C., pp. 438.

Alka Dev, Verma, P. and Bheru, L.K. 2017. Genetic Character Variability Studies in Desi Chickpea (Cicer arietinum L.) Genotypes. International Journal of Current Microbiology and Applied Sciences. 6(4): 20-25.

Bidlack, J.E., Rao, S.C. and Demezas, D.H. 2001. Nodulation, nitrogenous activity and dry weight of chickpea and pigeonpea cultivars using different Brady rhizobium strains. Journal of Plant Nutrition. 24 (3): 549-560.

Bouhadida, M., Benjannet, R., Jendoubi, W., Kharrat, M. 2015. Analysis of genetic diversity of Chickpea (Cicer arietinum L.) cultivars using STMS (Sequence Tagged Microsatellite Site) markers. Journal of Applied Chemistry (IOSR JAC). 8(2): 70-74.

Datta, R., and Sharma, R. 1999. Temporal and spatial regulation of nitrate reductase 
and nitrite reductase in greening maize leaves. Plant Science. 144: 77-83.

Fatima, Z., Bano, A., Sial, R. and Aslam, M. 2008. Response of chickpea to plant growth regulators on nitrogen fixation and yield. Pakistan Journal of Botany.40 (5): 2005-2013.

Ferari, T.E., and Varner, I.E. 1971. Intact tissue assay for nitrate reductase in barley aleurone layer. Plant Physiology.41: 790-994.

Garg, B.K., Kathju, S., Vyas, S.P. and Lahiri, A.N. 1997. Sensitivity of clusterbean to salt stress at various growth stages. Indian Journal of Plant Physiology. 2: 49-53.

Garg, N., and Singla, R. 2005. Nitrate reductase activity in roots and leaves of chickpea cultivars under salt stress. Spanish Journal of Agricultural Research. 3(2): 248-252.

Jeyakumar, P., Velu, G., Rajendran. C., Amutha, R., Sarvey, M.A.J.R. and Chidambaram, S. 2008. Varied responses of black gram (Vigna mungo) to certain foliar applied chemicals and plant growth regulators. Legume Research. 31 (2): 110-113.

Jukanti, A.K., Gaur, P.M., Gowda, C.L., Chibbar, R.N. 2012. Nutritional quality and health benefits of chickpea (Cicer arietinum L.): A review. British Journal of Nutrition. 108 (Suppl 1): S11-26.

Katiyar, S., and Dubey, R.S. 1992. Influence of $\mathrm{NaCl}$ salinity on behaviours of nitrate reductase and nitrite reductase in rice seedlings differing in salt tolerance. Journal of Agronomy and Crop Sciences. 169: 289-297.

Kaur, S., Gupta, A.K. and Kaur, N. 1998. Gibberelin $\mathrm{A}_{3}$ reverses the effect of salt stress in chickpea (Cicer arietinum L.) seedlings by enhancing amylase activity and mobilization of starch in cotyledons. Plant Growth Regulation. 26: $85-90$.
Khan, M.G., 1996. Nitrate and nitrite reductase activities in soybean plants raised with saline water. Indian Journal of Plant Physiology. 1(2): 128-129.

Khan, M.M.A., Gautam, C., Mohammad, F., Siddiqui, M.H., Naeem, M. and Khan, N. 2006. Effect of Gibberellic Acid Spray on Performance of Tomato. Turkish Journal of Biology. 30:11-16.

Khan, N.A., Ansari, H.R. and Mobin, M. 1996. Effect of gibberellic acid and nitrogen on carbonic anhydrase activity and mustard biomass. Biologia Plantarum. 38: 601-603.

Khan, N.A., Mir, R., Khan, M., Javid, S., and Samiullah 2002. Effects of Gibberellic acid spray on nitrogen yield efficiency of mustard grown with different nitrogen levels. Plant Growth regulation. 38(3): 243-247.

Mittal, M., and Koundal, K.R. 1990. Isolation and Characterization of Storage protein of developing seeds of chickpea (Cicer aeritinum L.).Indian Journal of Agricultural Biochemistry. 3(1\&2): 110.

Naqvi, S.S.M., 1994. Plant hormones and stress phenomena. In Pessarakli, $\mathrm{M}$. (Ed.). Handbook of Plant and Salt Stress. Marcel Dekker, New York.

Nicholos, D.J.D., and Nanson, A. 1957. Determination of nitrate and nitrite. In. Methods in Enzymology. 3: 981.

Patil, B.N., and Ghuge, V.Y. 1988. Physiological analysis of variability in chlorophyll nitrogen content and harvest index in some mutants of chickpea. Annals of Plant Physiology. 2(1): 1-6.

Raifa, A., Hassamin, H.K.I., Khatlab, H.M.S., Elbassiouny and Mervat, S. 2005. Increasing the active constituents of sepals of rosall (Hibiscus rabdariffa,) gibberellic acid and Benzyladenine. Journal of Applied Sciences Research. 1 (2):137-146. 
Rao, B.N.V., Manjunath, N.H. and Prasad, D.T. 1999. 2S albumins: a review. Journal of Plant Biology 26(1): 19-29.

Rathore, P.S., and Sharma, S.K. 2003. Scientific Pulse Production. Yash Publishing House. Bikaner, Rajasthan. pp. 92-122.

Seabra, M., Carvalho, S., Freire, J., Ferreira, R., Mourato, M., Cunha-L, Cabral F, Teixeira, A. and Aumaitre, A. 2001. Lupinus Luteus, Viciasativa and Lathyruscicera as protein sources forpiglets: ileal and total tract apparent digestibility of amino acid and antigenic effect. Animal Feed Science and Technology.89:1-2, 1-16.

Senthil, A., Pathmanaban, G. and Srinivasan, P.S. 2008. Effect of bioregulators on some physiological and biochemical parameters of soyabean (Glycine max. L.). Legume Research. 26 (1): 54-56.
Singh, N.P., (2010) Project Coordinators Report. In AICRP on chickpea, IIPR, Kanpur-208024.

Solomonson, L.P., and Barber, M.J. 1990. Assimilatory nitrate reductase functional properties and regulation. Annual Review of Plant Physiology and Plant Molecular Biology. 41: 225-253.

Tyagi, P.S., Singh, B.D. and Jaiswal, N.K. 1982. High seed protein percentage in chickpea II. Comparative nitrogen accumulation patterns. International Chickpea Newsletter. 6: 6-8.

Vesna, D., Suzana, K., Zoran, D., Zoran, D., and Natalija, K. 2015. Variations in level of oil, protein, and some antioxidants in chickpea and peanut seeds. Chemical and Biological Technologies in Agriculture. 2: 2.

Vyas, I., and Puranik, R. 1993. Inhibition of NRA by mercury in bean leaf segment. Indian Journal of Plant Physiology. 36(1): 55-60.

\section{How to cite this article:}

Preeti Singh Arya, Jagdish Singh Arya and Singh, R.P. 2018. The Possible Involvement of Exogenous Gibberellic Acid on Nitrogen Assimilating Enzyme Activity and Total Nitrogen Content in Chickpea (Cicer aeritinum L.) Genotypes. Int.J.Curr.Microbiol.App.Sci. 7(04): 2403-2412. doi: https://doi.org/10.20546/ijcmas.2018.704.276 